\section{AEE \\ RESEARGH and}

DeVELOPMENT REPORT

\section{MELTING POINTS \\ of \\ HYPOSTOICHIOMETRIC URANIUM DIOXIDE}

By

J. LAMBERT BATES

JUNE, 1966

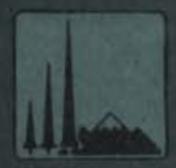

BATTELLE MEMORIAL INSTITUTE/PACIFIC NORTHWEST LABORATORY

\section{DAtTELLENNORTHWEST}




\section{LEGAL NOTICE}

This report was prepared as an account of Government sponsored work. Neither the United States, nor the Commission, nor any person acting on behalf of the Commission:

A. Makes any warranty or representation, expressed or implied, with respect to the accuracy, com. pleteness, or usefulness of the information contained in this report, or that the use of any information, apparatus, method, or process disclosed in this report may not infringe privately owned rights; or

B. Assumes any liabilities with respect to the use of, or for damages resulting from the use of any information, apparafus, method, or process disclosed in this report.

As used in the above, "person acting on behalf of the Commission" includes any employee or contractor of the Commission, or employee of such contractor, to the extent that such employee or confractor of the Commission, or employee of such contractor prepares, disseminates, or provides access to, any information pursuant to his employment or contract with the Commission, or his employment with such contracior.

\section{PACIFIC NORTHWEST LABORATORY \\ RICHLAND, WASHINGTON \\ operated by}

BATTELLE MEMORIAL INSTITUTE

for the

UNITED STATES ATOMIC ENERGY COMMISSION UNDER CONTRACT AT(45-1)-1830 
BNWL -224

UC-25, Metals, Ceramics, and Materials

\title{
MELTING POINTS OF HYPOSTOICHIOMETRIC URANIUM DIOXIDE
}

\author{
Linatin. \\ By \\ J. Lambert Bates \\ Ceramics and Graphite Research Section \\ Materials Department
}

June , 1966

PACIFIC NORTHWEST LABORATORY

RICHLAND, WASHINGTON 


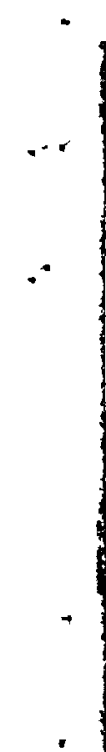


MELTING POINTS OF HYPOSTOICHIMETRIC

URANIUM DIOXIDE

J. Lambert Bates

\section{INTRODUCTION}

Recent interest in the properties of hypostoichiometric $\mathrm{UO}_{2}$ and high temperature $\mathrm{U}-\mathrm{UO}_{2}$ phase relationships ${ }^{(1-3)}$ has motivated further melting point studies of nonstoichiometric $\mathrm{UO}_{2}$.

The reported melting point for U0 2 varies between $2174{ }^{\circ} \mathrm{C}$ and $2880{ }^{\circ} \mathrm{C}^{(4-15)}$ with most recent values between $2750{ }^{\circ} \mathrm{C}$ and $2880{ }^{\circ} \mathrm{C}$. However, most melting point data are reported for nearly stoichiometric compositions. Christensen (11) reported a $2400{ }^{\circ} \mathrm{C}$ melting point for hyperstoichiometric $\mathrm{UO}_{2.15}$. Duncan et al. (13) indicated that the melting point for $\mathrm{UO}_{1.96}$ was approximately $100{ }^{\circ} \mathrm{C}$ higher than the melting point for $\mathrm{UO}_{2.0}$. Conversely, Latta and Fryxe11(15) recently reported that the melting points for nonstoichiometric $\mathrm{UO}_{2} .003$ to $\mathrm{UO}_{1.75}$ decreased with decreasing $0: U$ ratio

This note reports the melting points for hypostoichiometric $\mathrm{UO}_{2.00}$ to $\mathrm{UO}_{1.67^{\circ}}$. The melting points decreases below 2.00 agreeing in general with the results of Latta and Fryxe11. (15) However, the melting point of $\mathrm{UO}_{2.00}$ is lower than that reported by Latta and Fryxe11, and the melting points of the most hypostoichiometric $\mathrm{UO}_{2-\mathrm{x}}$ are higher. The data also suggest a possible maximum in the melting point at a stoichiometry less than 2.00 .

\section{EXPERIMENTAL TECHNIQUE}

Fabrication of Hypostroichiometric oxide

Uranium dioxide cylinders with large axial holes were filled with uranium metal (2) and were encapsulated in tungsten crucibles. These crucibles were heated for 10 to 240 minutes at $1600{ }^{\circ} \mathrm{C}$ to $2500^{\circ} \mathrm{C}$ in $10^{-5}$ torr vacuum. After cooling, each cylinder was examined ceramographically; and the $0: U$ ratio of the originally stoichiometric $\mathrm{UO}_{2}$ was determined gravimetrically by oxidation to $\mathrm{U}_{3} \mathrm{O}_{8}$.

The microstructure of the hypostoichiometric $\mathrm{UO}_{2}$ consisted of twophase polycrystalline $\mathrm{UO}_{2}$ with uranium metal uniformly dispersed in the grain boundaries. The final $0: \mathrm{U}$ ratios of the samples were controlled by varying the heating temperature: the higher the temperature, the lower the $0: U$ ratio. $(1-2)$ 


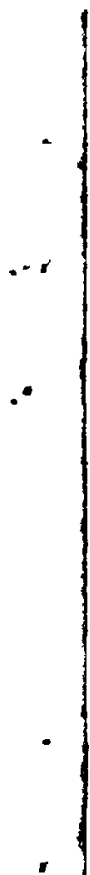

.

:

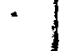

.

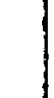
$\cdot$ 


\section{Melting Point Determinations}

Melting points were determined in purified inert atmospheres* using an electric tungsten "V" filament furnace. (11) Small, 10-25 mg samples of the oxide were placed in the bottom of the filament. Specimen melting was observed using a long working distance microscope, and simultaneously, filament temperatures were measured using an optical brightness pyrometer. The time required to measure a single melting point was less than 5 seconds. The system was calibrated using materials of known melting points $\left(\mathrm{Al}_{2} \mathrm{O}_{3}\right.$, $\mathrm{Cu}, \mathrm{Nb}, \mathrm{Mo}, \mathrm{Pt}, \mathrm{Ni}$ ). Three to ten measurements wera made of each specimen. Precision of the temperature measurements is within $\pm 25^{\circ} \mathrm{C}$, and standard mean deviations are less than $\pm 25^{\circ} \mathrm{C}$ (Table I).

TABLE I. Melting Points of Hypostoichiometric Uranium Dioxide

\begin{tabular}{|c|c|c|c|}
\hline 0:U Ratio & $\begin{array}{l}\text { Melting Point } \\
{ }^{\circ} \mathrm{C} \\
\end{array}$ & $\begin{array}{c}\text { Mean } \\
\text { Deviation }\end{array}$ & $\begin{array}{r}\text { Number of } \\
\text { Samples } \\
\end{array}$ \\
\hline 2.002 & 2790 & \pm 17 & 3 \\
\hline 2.001 & 2804 & \pm 13 & 9 \\
\hline 1.922 & 2792 & \pm 9 & 10 \\
\hline 1.917 & 2735 & \pm 25 & 4 \\
\hline 1.889 & 2744 & \pm 19 & 3 \\
\hline 1.878 & 2703 & \pm 22 & 4 \\
\hline 1.871 & 2716 & \pm 28 & 3 \\
\hline 1.868 & 2746 & \pm 8 & 3 \\
\hline 1.841 & 2701 & \pm 21 & 6 \\
\hline 1.823 & 2721 & \pm 12 & 3 \\
\hline 1.803 & 2681 & \pm 8 & 3 \\
\hline 1.794 & 2698 & \pm 17 & 3 \\
\hline 1.792 & 2627 & \pm 22 & 8 \\
\hline 1.780 & 2603 & \pm 17 & 10 \\
\hline 1.778 & 2664 & \pm 25 & 3 \\
\hline 1.735 & 2648 & \pm 24 & 7 \\
\hline 1.713 & 2568 & \pm 27 & 7 \\
\hline 1.686 & 2533 & \pm 31 & 5 \\
\hline
\end{tabular}

* The argon and 8\% hydrogen-argon contained less than $l \mathrm{ppm} \mathrm{O}_{2}$ and less than $5 \mathrm{ppm} \mathrm{H} \mathrm{H}^{\mathrm{O}}$.

\section{DATA AND RESULTS}

The melting point of hypostoichimetric $\mathrm{UO}_{2-\mathrm{x}}$ decreases with decreasing $0: U$ ratio between 2.00 and 1.67 .

The melting point for stoichiometric $\mathrm{UO}_{2}$ agrees with that $\left(2805^{\circ} \mathrm{C}\right)$ reported by Hausner, (14) but is lower than the $2880{ }^{\circ} \mathrm{C}$ melting point reported by Latta and Fryxel1. (15) The reason for these differences is not apparent. The variation cannot be attributed solely to the different techniques since Hausner ${ }^{(14)}$ and Latta and Fryxe11(16) employed a similar thermal arrest method.

The melting point values reported here at $0: U$ ratios less than 2.00 vary from those reported by Latta and Fryxe11. A1though both show a significant decrease in the melting point for $\mathrm{UO}_{2-\mathrm{x}}$, their values are higher near $\mathrm{UO}_{2.00}$ and lower for the lower $0: U$ ratios.

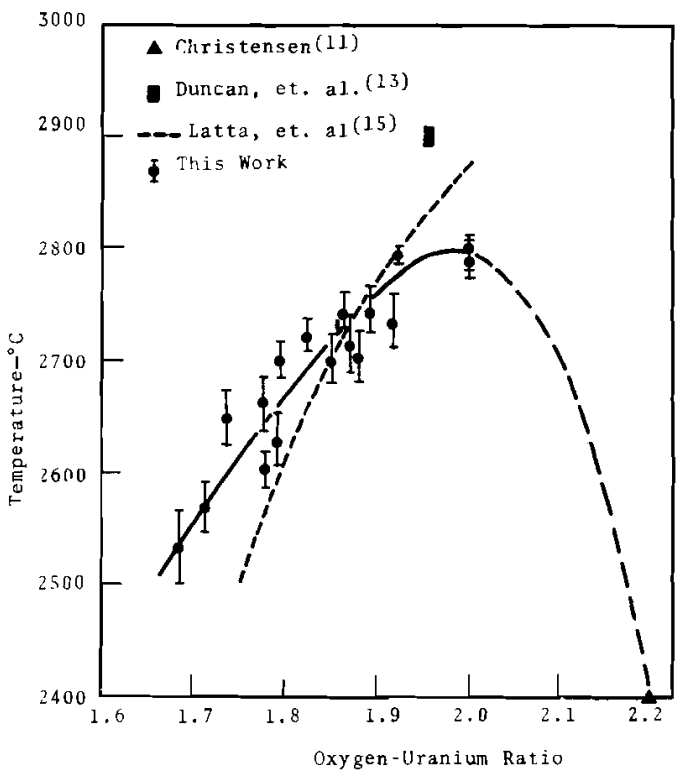

FIGURE 1. Melting Points of Hypostoichiometric Uranium Dioxide 


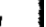


Samples with 0:U ratios substantially less than 2.00 melted at lower temperatures during the initial melting point determination than during subsequent remelting. For example, the initial melting point of a $\mathrm{UO}_{1.71}$ sample was $2550^{\circ} \mathrm{C}$. The second and third melting points of the same sample were $2600{ }^{\circ} \mathrm{C}$ and $2660^{\circ} \mathrm{C}$, respectivly. After heating near $2500^{\circ} \mathrm{C}$ for approximately three minutes, the sample melted at $2790^{\circ} \mathrm{C}$. Only the initial melting point for each sample is reported.

The melting point changes resulting during melting and heating are undoubtedly caused by $0: U$ ratio changes occurring during melting. Although a purified argon or $8 *$ hydrogen-argon atmosphere was used during the melting point determinations, the oxygen partial pressure was still sufficiently large to increase the $0: U$ ratio during heating. (3)
This compositional variation during the melting point determinations suggests that the actual melting points in the very low substoichiometric oxide may be lower than those reported because a small, but finite time was required to measure the melting point.

The portion of the melting point curve near stoichiometry remains uncertain. Although not shown conclusively, a maximum in the melting point curve possibly exists between $\mathrm{UO}_{2.00}$ and $\mathrm{UO}_{1.93}$. Compounds which dissociate at high temperatures need not exhibit a maximum melting point at the stoichimetric composition of the compound. (16) The maximum in the liquidus curve possesses a horizontal tangent. The sharpness of the maximum gives some indication of the degree of dissociation: the sharper the maxima, the less the degree of dissociation. Since the slope of the $\mathrm{UO}_{2+\mathrm{x}}$ liquidus is greater than the slope of the $\mathrm{UO}_{2-\mathrm{x}}$ liquidus, the maximum, if it occurs, should occur at a hypostoichiometric composition. (16) 


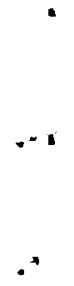




\section{References}

1. R. K. Edwards and A. E. Martin. "Phase Relations in the UraniumUranium Dioxide System and High Temperatures," Symposium on Thermodynamics with Emphasis on Nuclear Materials and Atomic Transport in Solids, SM-66/81, Vienna, Austria, July 22-27, 2965

2. J. L. Bates, "Ionic Diffusion in High Temperature Uranium Dioxide" Symposium on Thermodynamics with Emphasis on Nuclear Materials and Atomic Transport in Solids, SM-66/67, Vienna, Austria, July $22-27, \quad 2965$

3. E. A. Aitken, H. C. Brassfield and R. E. Fryxelz, "Thermodynamic Behavior of Hypostoichiometric UO ," Symposium on Thermodynamics with Emphasis on Nuclear Materials and Atomic Transport in Solids SM-66/83, Vienna, Austria, also GE-TM 65-6-13, Elight Propulsion Laboratory, Cincinnati. 2965

4. 0. Ruff and D. Goecke, "Melting and Vaporization of High Temperature Refractories", Z. Ang. Ch. vol $24, p 1459.1911$

5. E. Friederick and L. Sitting, Z.Anorg, u. Alzg. Ch., vol 145, p. 127.2925

6. W. A. Lambertson and J. H. Handwick The Fabrication and Physical Properties of Urania Bodies, $A N L-5053$, Argonne National Laboratory, Feb. 1956

7. L. G. Wisnyi and S. Pihanowski, The Thermal Stability of Uranium Dioxide, KAPL-1702, Knolls Atomic Power Laboratory. Nov. 1, 1957
8. T. C. Ehlert and J. L. Margrove, "Melting Point and Spectral Emissivity of Uranium Dioxide," J. Am. Ceram. Soc. vol 41, p. 330. 1958

9. H. W. Newkirk and J. L. Bates, Melting Points of UO,UC and UN HW-59468, General Eléctric, Richland, Washington. 1959

10. R. M. Powers, Y. Cavalzaro and J. P. Mathern, The Effect of Solid Solution Addition on the Thermal Conductivity of UO, SCNC-317 Sylvania-Corning Nuclear Corp. 2960

11. J. A. Christensen, Irradiation Effects on Uranium Dioxide Melting, HW-69234, General Electric, Richland, Washington. March 2962

12. T. D. Chikalla, "Melting Behavior in the System UO $-\mathrm{PuO}_{2}$ ", J.Am. Ceram. Soc. vol 6 , pp.' $3 \overline{23-328}$, 1963

13. R. N. Duncan and H. M. Ferrari "Preparation and Properties of Hypostoichiometric Uranium Dioxide", Trans. Am. Nucl. Soc. vol 6, no. 1 pp. 154-155, 1963

14. H. Hausner, "Determination of the Melting Point of Uranium Dioxide", J. Nucl. Mat. vol 15, no. 3 pp. 179-183, 1965

15. R. E. Latta and R. E. Fryxezl, Determination of the Melting Point of UO $2+x \frac{(-0.25<x<0)}{\text {, }}$ GE-TM-65-11-8, Flight Propulsion Laboratory, Cincinnati. Nov. 26, 2965

16. J. Zernike, "Chemical phase Theory", N.V. Uitgevers-Maatschappij $A E$. E. Kluwer, Deventer-AntwerpDjakarta, pp. 227-232, 2955 


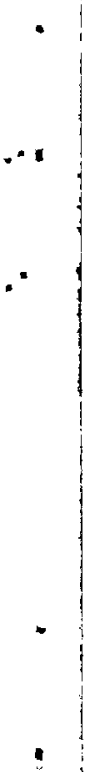




\section{DISTRIBUT ION}

No. of Copies

A1 lgemeine Eleklugitats Gesselschaft, Frankfurt AEG Hochhaus, Federa1. Republic of Germany, $\mathrm{J}$. Hoche 1

4

Argonne National Labora tory

R. K. Edwards

J. H. Handwerk

J. H. Kitte 1

R. J. Thorn

7

USAEC, Washington

Division of Reactor Development

R. Grube

H. B. Finger

J. M. Morrissey

F. C. Shwenk

J. M. Simmons

W. R. Voigt

M. J. Whitman

1 USAEC, Washington

Division of Research W. F. Sheely

3 Atomic Energy of Canada

Chemistry and Metallurgy

Branch Fuels Development Branch

J. A. L. Robertson

J. R. MacEwan

M. F. Notley

5

United Kingdom Atomic

Energy Authority

Atomic Energy Research

Establishment

Harwe11, Didcot, Berks, Eng 1 and

P. Murray (3)

L. E. Russe11

J. Williams

1

Atomics International

Attn: B. R. Hayward

2 Atomic Power Development Associates

W. H. Jens

A. A. Shoudy

3
No. of Copies

1

Centre d'Etudes Nucleaires

de Cadarache

Boite Postale No. 1

Saint-Pau1-Lez-Durance,

France

Dr. B. Devreyn

1

C. E. N. - Belgonucleaire

Mol, Belgium

J. M. Leblanc

1

Tokyo Shibaura Electric

Company, Ltd.

Central Research Labora-

tory

Komukai, Kawasaki, Japan

T. Nishijima

Conute National pour

I'Energie Nucleare

Casaccia, Centre

Rome, Ita1y

Attn: S. Moretti

Division of Technical Information Extension

1

European Atomic Energy

Community

(Euratom)

51-53 Rue Bel1iard

Brussels 4, Belgium

Pierre Kruys

General Electric Company,

APD

Special Purpose Nuclear

Systems Operation

P.O. Box 450

Palo Alto, California

H. Miller

2

Genera1 Electric Company,

Cincinnat $i$

R. E. Fryxe11

R. E. Latta

3

General Electric Company, pleasanton

E. A. Evans

L. P. Bupp

M. Sanderson

Genera1 Electric Company, San Jose

K. Cohen

A. N. Holden

M. F. Lyons

T. J. Pashos 

No. of Copies

1 Kerr-McGee Industries, Inc. oklahoma City, Okla.

H. Lambertus

1

Knolls Atomic Power

$\frac{\text { Laboratory }}{\text { W. K. Barney }}$

5

Los Alamos Scientific

Laboratory

M. Bowman

R. Spence

D. MCMi11 an

R. Baker

H. Hessing

Oak Ridge National

Laboratory

Research Materials

Information Center

P. O. Box X

Oak Ridge, Tennessee

37831

T. F. Connal1y

3

Richland Operations

office

P. G. Holsted

R. K. Sharp

Technical Information

Laboratory

1

Siemens-Schuckertwerks

Abt. R. $\overline{\mathrm{E}}$.

852 Erlangen

Federa1 Republic of

Germany

R. Ho1tzer

3

Union Carbide Corporation (ORNL)

R. M. Carrol1

J. L. Scott

W. C. Thurber

1

United Aircraft Corpor-

ation

Research Laboratory

East Hartford, Connecticut

G. H. Mclafferty

1
No. of Copies

1 University of Michigan

Ann Arbor, Michigan

w. Kerr, College

of Engineering

3

USAEC, Scientific Advisor

Avenue des Arts

Brussels, Belgium

G. E. Helfrich

Westinghouse Electric

Corporation

Robert A11io

A. Boltax

Westinghouse Bettis Atomic Power Laboratory

J. Belle

B. Lustman

Wright Air Development Center

AF Materials Laboratory Wright-Patterson AFB, Dayton, Ohio

S. W. Bradstreet

Battelle-Northwest

R. J. Baker

J. L. Bates

T. E. Bauer

T. D. Chikalla

J. A. Christensen

R. E. Dah1

G. M. Dalen

J. L. Danie 1

D. R. DeHalas

K. Drumheller

P. L. Farnsworth

R. L. Gibby

W. L. Hampson

G. R. Horn

C. E. McNeil1y

R. P. Nelson

R. E. Nightingale

W. E. Roake

R. K. Robinson

R. E. Skavdah 1

R. C. Smith

H. A. Taylor

G. L. Tingey

E. T. Weber

H. H. Yoshikawa

Technical Publications

Technical Information

Files 


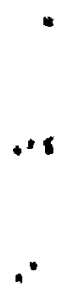

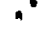

